Elsevier

BRE 11826

\title{
Characterization of the Forms of $\beta$-Endorphin and $\alpha$-MSH in the Caudal Medulla of the Rat and Guinea Pig
}

\author{
ROBERT M. DORES*, MONICA JAIN and HUDA AKIL \\ University of Michigan School of Medicine, Mental Health Research Institute, Ann Arbor, MI 48109 (U.S.A.)
}

(Accepted November 19th, 1985)

Key words: $\beta$-endorphin - $\alpha$-melanocyte-stimulating hormone - medulla oblongata - nucleus tractus solitarius post-translational processing - acetylation - mammalian central nervous system

\begin{abstract}
The post-translational processing of pro-opiomelanocortin (POMC) in brain remains controversial. Classically, there was thought to be a single cell group in the arcuate nucleus with long projections through limbic structures. More recently, a second cell group was discovered in the caudal medulla. This study addresses the question of POMC processing in this region. Steady-state analysis of acid extracts of dorsal caudal medulla from rat and guinea pig CNS by gel filtration chromatography and radioimmunoassay indicated that in both species the major POMC-related end products are $\alpha$-MSH-sized material and $\beta$-endorphin-sized. In this tissue $\beta$-LPH and ACTH represent minor end products. Analysis of the $\alpha$-MSH-sized material from both species by reverse-phase HPLC indicated that in the rat caudal medulla approximately $79 \%$ of the $\alpha$-MSH-related material is acetylated, and in the guinea pig caudal medulla approximately $85 \%$ of the $\alpha$-MSH-related material is acetylated. Analysis of the forms of $\beta$-endorphin isolated from the rat caudal medulla by cation exchange chromatography revealed that acetylated and non-acetylated forms of $\beta$-endorphin are present in this region of the rat CNS. Approximately $65 \%$ of the $\beta$-endorphin in the rat caudal medulla is $\mathrm{N}$-acetylated. Analysis of the forms of $\beta$-endorphin isolated from the guinea pig caudal medulla indicated that approximately $63 \%$ of the $\beta$-endorphin is $\mathrm{N}$-acetylated in this region of the guinea pig CNS. These data indicate that the post-translational processing of POMC in the dorsal caudal medulla, the site of the nucleus tractus solitarius POMC cell group, is distinct from the processing patterns that have been reported for POMC systems in the mammalian anterior pituitary, intermediate pituitary and arcuate nucleus.
\end{abstract}

\section{INTRODUCTION}

End products derived from the post-translational processing of the polyprotein, pro-opiomelanocortin (POMC), the common precursor for ACTH-related and $\beta$-LPH-related polypeptides, are distributed widely throughout the pituitary and brain (for reviews see refs. 3, 27). As a result of differential posttranslational processing, POMC can be processed to yield tissue-specific sets of end products. In corticotropic cells of the anterior pituitary, POMC is proteolytically cleaved to yield $16 \mathrm{kDa}$ fragment (the $\mathrm{N}$-terminal third of the precursor), $\mathrm{ACTH}_{1-39}, \beta$-lipotropin and non-acetylated $\beta$-endorphin ${ }_{1-31}$ as major end products $^{9}$. In melanotropic cells of the intermediate pituitary post-translational processing of POMC will yield peptides related to $16 \mathrm{kDa}$ fragment ${ }^{17,20}$, N-acetylated forms of $\alpha$-MSH [N-acetyl-ACTH ${ }_{1-13} \mathrm{a}$ mide $]^{5,29}$ and $\mathrm{N}$-acetylated forms of $\beta$-endorphin $^{4,18,26,32-34}$ as major end products. The consequences of differential post-translational processing are particularly striking with respect to $\beta$-endorphin, where $\mathrm{N}$-acetylation results in a dramatic drop in opiate receptor binding activity ${ }^{2,7}$.

Studies on the distribution of POMC-related products in the brain have largely focused on the arcuate nucleus system (for review see ref. 22). Steady-state analyses of the forms of POMC-related products in the arcuate region are in general agreement that: (1) $\alpha$-MSH-sized material and $\beta$-endorphin-sized material are the major POMC products present in this region of the hypothalamus ${ }^{16,23}$; and (2) the $\alpha$-MSH-

\footnotetext{
* Present address: University of Denver, Department of Biological Sciences, Denver, CO 80208, U.S.A.

Correspondence: H. Akil, University of Michigan, Mental Health Research Institute, 205 Washtenaw Place, Ann Arbor, MI 48109, U.S.A.
} 
sized material is predominantly non-acetylated $\mathrm{ACTH}_{1-13}$ amide and the $\beta$-endorphin-sized material is predominantly non-acetylated $\beta$-endorphin ${ }_{1-31}$ (refs. 11, 14, 24, 25, 32-34). Thus at this level of analysis the arcuate POMC system resembles the intermediate pituitary system in terms of the extent of proteolytic cleavage, but differs from the latter system in the degree of $\mathrm{N}$-acetylation of the end products. In addition, recent dynamic in vivo pulse labelling studies of the arcuate nucleus indicate that although the end results of proteolytic cleavage of POMC in the arcuate system and the intermediate pituitary system are similar, the steps in the proteolytic cleavage pathway appear to be unique for each system ${ }^{24}$.

Although there is general agreement on the forms of $\alpha$-MSH and $\beta$-endorphin in the hypothalamus, studies of the forms of these peptides in the remainder of the brain have yielded conflicting results. In some studies, analysis of whole brain extracts have revealed the presence of only non-acetylated forms of $\alpha$-MSH and $\beta$-endorphin ${ }^{14,32}$, whereas, other studies have reported acetylated $\alpha$-MSH ${ }^{25,28}$ and acetylated forms of $\beta$-endorphin ${ }^{33}$ in extracts of brain. Given the effects of $\mathrm{N}$-acetylation on opiate receptor binding activity and the implication this would have on the ability of $\beta$-endorphin to function as a neuromodulator, it is essential to clarify which forms of $\beta$ endorphin are present in different regions of the brain.

The issue of acetylated forms of $\alpha$-MSH and $\beta$-endorphin has focused on the arcuate POMC system, however, recent immunohistochemical studies on the medulla oblongata have detected another POMC perikarya network in the area of the nucleus tractus solitarius (NTS) ${ }^{19-21.30}$. In addition analyses of extracts of the brainstem have detected both acetylated and non-acetylated forms of $\beta$-endorphin in this region of the brain ${ }^{34}$. One of the functions of the NTSvagal complex is the regulation of cardiovascular function and, accordingly, there is an extensive literature on the mixed effects of exogenously administered opioids on cardiovascular regulation ${ }^{18}$. Against this background, it seems essential at this point to establish the molecular forms of the opioids present in this region of the medulla. Based on these considerations, the objectives of this study were to determine the steady-state levels of POMC-related products in the nucleus tractus solitarius (NTS) and surrounding tissue, and to determine whether acetylated forms of $\alpha$-MSH and $\beta$-endorphin are present in the dorsal caudal medulla. This study compares the distribution of these peptides in two species of rodents: the rat and the guinea pig.

\section{MATERIALS AND METHODS}

\section{Dissection and processing of tissues}

For these studies male Sprague-Dawley rats (wet weight: $200-250 \mathrm{~g}$ ) and male Hartley guinea pigs (wet weight: $200-275 \mathrm{~g}$ ) were purchased from Charles River. The animals were held at $22{ }^{\circ} \mathrm{C}$ on a $11 \mathrm{~h}: 13 \mathrm{~h}$ light/dark cycle. The animals were sacrificed in the morning between 09.00 and $11.00 \mathrm{~h}$ by decapitation and the brains were rapidly removed and dissected on ice. The dorsal surface of the medulla oblongata was exposed by removing the cerebellum and a section of the dorsal caudal medulla just posterior to the obex was dissected for analysis. This section included the NTS, as well as, the dorsal vagal nucleus, the hypoglossal nucleus, the nucleus commissuralis, the nucleus gracilis, the nucleus cuniformis, and the fasciculus cuneiformis, but excluded the nucleus ambiguus, the nucleus tractus olfactorius lateralis, the tractus corticospinalis, the nucleus raphe magnus and the nucleus reticularis lateralis. For the rat dissection the average wet weight of the tissue was $95 \mathrm{mg}$, and for the guinea pig the average wet weight of the tissue was $105 \mathrm{mg}$. For each dissection, the tissue was placed on dry-ice, weighed, pooled and extracted in 10 vols. of acetone $/ 0.1 \mathrm{~N} \mathrm{HCl}$ (3:1) which contained $0.3 \%$ phenylmethylsulfonyl fluoride. The homogenate was centrifuged at $10,000 \mathrm{rpm}$ for $60 \mathrm{~min}$, and the supernatant was concentrated under vacuum (Savant Speed Vac). The dried extract was redissolved in $1.2 \mathrm{ml}$ of $10 \%$ formic acid which contained $0.01 \%$ bovine serum albumin and $0.1 \% 2$ mercaptoethanol. Control experiments with radiolabelled polypeptides indicated that the recovery at each step in this isolation averaged $88 \%$.

\section{Gel filtration chromatography}

Tissue extracts were fractionated on a Sephadex G-50 superfine column $(1 \times 100 \mathrm{~cm}$; Pharmacia $)$ equilibrated in $10 \%$ formic acid $/ 0.01 \%$ bovine serum albumin $/ 0.1 \%$ 2-mercaptoethanol buffer. The col- 
umn was developed at a flow rate of $2 \mathrm{ml} / \mathrm{h}$ and $1.0 \mathrm{ml}$ fractions were collected. The void volume was marked with bovine serum albumin ( $1 \mathrm{mg} / \mathrm{sample}$ volume) and the total volume was marked with 2-mercaptoethanol (75 $\mu \mathrm{l} / \mathrm{sample}$ volume). Both of these markers were detected spectrophotometrically at A-280. The following standards were run on this column: cytochrome $\mathrm{C}$, synthetic human $\beta$-endor$\operatorname{phin}_{1-31}$, and synthetic $\mathrm{N}$-acetyl- $\mathrm{ACTH}_{1-13}$ amide $(\alpha-\mathrm{MSH})$. Aliquots of column fractions were concentrated and separately analyzed by radioimmunoassay (RIA) with antiserum specific for $\alpha$-MSH, $\beta$-endorphin, and ACTH. The recovery of immunoreactivity from this column averaged $88 \%$.

\section{Reverse-phase high-performance liquid chromato- graphy}

The fractions of immunoreactive material from Sephadex G-50 chromatography which corresponded to $\alpha$-MSH-sized material were fractionated by reverse-phase high-performance liquid chromatography (HPLC) on a Beckman C-18 ODS ultrasphere $5 \mu \mathrm{m}$ column $(4.6 \mathrm{~mm} \times 25 \mathrm{~cm})$ equilibrated in $0.1 \%$ trifluoroacetic acid following the procedure described by Browne et al. ${ }^{5}$. The system was eluted with a 4-40\% non-linear gradient of acetonitrile in $0.1 \%$ trifluoroacetic acid. The flow rate was $1 \mathrm{ml} / \mathrm{min}$ and the fraction size was $0.5 \mathrm{ml}$. Aliquots of column fractions were concentrated and analyzed with an $\alpha$-MSH RIA. The recovery of immunoreactivity averaged $93 \%$. Following the fractionation of the rat and guinea pig material, the following synthetic peptides were run as standards and detected spectrophotometrically at A-225: $\mathrm{ACTH}_{1-13}$ amide, $\mathrm{N}$-acetyl$\mathrm{ACTH}_{1-13}$ amide, N,O-diacetyl-ACTH${ }_{1-13}$ amide all purchased from Bachem (Torrance, CA).

\section{Ion exchange high-performance liquid chromato- graphy}

The fractions of immunoreactive material from Sephadex G-50 chromatography which corresponded to $\beta$-endorphin-sized material were pooled, concentrated and fractionated by ion exchange HPLC on a Bio-Sil TSK CM-2SW column $(4.6 \mathrm{~mm} \times 25 \mathrm{~cm})$ following a modification of the procedure of Emenson $^{11}$. This ion exchange HPLC procedure has been modified as described below. It was validated by comparison to the established reverse-phase sys- tem ${ }^{1}$, and by simultaneous chromatography of the intermediate lobe with both systems, leading to identical conclusions about stored $\beta$-endorphin forms (Akil, Ueda and Lin, in preparation). The column was eluted with a linear ammonium formate gradient in $30 \%$ acetonitrile at $\mathrm{pH} 2.5$. For buffer $\mathrm{A}$ the ammonium ion concentration was $1.3 \mathrm{mM}$ and the formate ion concentration was $22 \mathrm{mM}$. For buffer $B$ the ammonium ion concentration was $26 \mathrm{mM}$ and the formate ion concentration was $450 \mathrm{mM}$. The flow rate was $0.6 \mathrm{ml} / \mathrm{min}$ and the fraction size was $0.3 \mathrm{ml}$. Aliquots of column fractions were concentrated and analyzed separately with the $\beta$-endorphin RIA and the $\mathrm{N}$-acetyl- $\beta$-endorphin RIA. The recovery of immunoreactivity averaged $95 \%$.

The TSK CM system, like the Sulfopropyl Sephadex ion exchange system developed by Zakarian and $\mathrm{Smyth}^{34}$, takes advantage of the fact that synthetic camel $\beta$-endorphin ${ }_{1-31}$ has a net positive charge of 7 at $\mathrm{pH} 2.5$. Fig. 1 plots the retention times of four forms of $\beta$-endorphin as a function of the theoretical net positive change of each form at $\mathrm{pH} 2.5$. This figure demonstrates that synthetic camel $\beta$-endorphin $_{1-31}, \mathrm{~N}$-acetyl- $\beta$-endorphin ${ }_{1-31}, \beta$-endorphin ${ }_{1-27}$, and $\mathrm{N}$-acetyl- $\beta$-endorphin ${ }_{1-27}$ can be readily sepa-

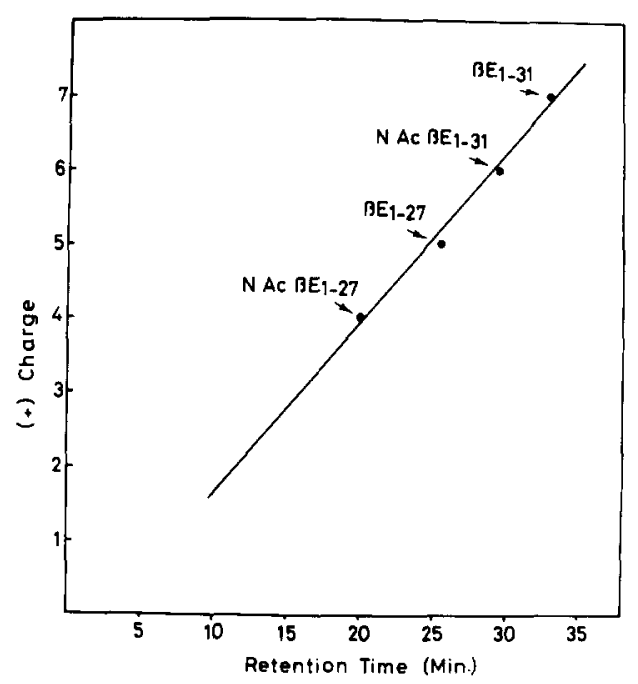

Fig. 1. A plot of the retention times of various forms of $\beta$-endorphin as a function of net positive charge at $\mathrm{pH} 2.5$. Various synthetic camel $\beta$-endorphin standards were chromatographed on the TSK CM-2SW HPLC system as described in Methods. The standards were detected spectrophotometrically at A-254. Abbreviations: $\quad \mathrm{N}-\mathrm{Ac}_{\mathrm{c}} \mathrm{BE}_{1-27}-\mathrm{N}$-acetyl- $\beta$-endorphin ${ }_{1-27}$; $\mathrm{BE}_{1-27}-\beta$-endorphin $n_{1-27} ; \mathrm{N}-\mathrm{Ac}-\mathrm{BE}_{1-31}-\mathrm{N}$-acetyl- $\beta$-endorphin $_{1-31} ; \mathrm{BE}_{1-31}-\beta$-endorphin ${ }_{1-31}$. 
rated in this system. On the basis of theoretical charge $\beta$-endorphin ${ }_{1-26}$ should have the same retention time as $\mathrm{N}$-acetyl $\beta$-endorphin ${ }_{1-27}$, and in our hands these two standards eluted as overlapping peaks in this system (data not shown).

\section{Radioimmunoassays}

Synthetic human $\mathrm{ACTH}_{1-39}$, synthetic $\mathrm{N}$-acetyl$\mathrm{ACTH}_{1-13}$ amide, synthetic human $\beta$-endorphin ${ }_{1-31}$ and synthetic camel $\mathrm{N}$-acetyl- $\beta$-endorphin ${ }_{1-27}$ all purchased from Bachem were used as standards. Peptides were iodinated by the chloramine-T procedure $^{1}$. $\alpha$-MSH, $\beta$-endorphin and $\mathrm{N}$-acetyl $-\beta$-endorphin RIAs were done in $150 \mathrm{mM}$ sodium phosphate, $0.1 \%$ bovine serum albumin, $\mathrm{pH} 8.2$ buffer. ACTH RIAs were done in $150 \mathrm{mM}$ sodium phosphate, 120 $\mathrm{mM}$ sodium chloride, $\mathrm{pH} 7.6$ buffer which contained $1 \%$ polylysine, $0.02 \%$ Triton $\mathrm{X}-100$, and $4 \mathrm{mM}$ EDTA. The reaction volume was $0.2 \mathrm{ml}$. Assays were incubated for $18-24 \mathrm{~h}$ at $4{ }^{\circ} \mathrm{C}$ and terminated by the double antibody procedure.

$\beta$-Endorphin RIA. Antiserum Brenda (final dilution: $1: 30,000$ ) is specific for the middle region of $\beta$-endorphin ${ }^{4}$ (i.e. residues $17-31$ ). This antiserum recognizes pro-opiomelanocortin and $\beta$-LPH, and has $85 \%$ molar cross-reactivity with $\beta$-endorphin ${ }_{1-27}$, but less than $0.1 \%$ molar cross-reactivity with $\alpha$-endorphin $_{1-16}$ or Met-enkephalin. The midpoint of this assay averaged $35 \mathrm{fmol} /$ tube.

$N$-Acetyl- $\beta$-endorphin RIA. Antiserum Nancy Beth (final dilution: 1:6000) is specific for $\mathrm{N}$-acetylated forms of $\beta$-endorphin. This antiserum fully recognizes $\mathrm{N}$-acetyl- $\beta$-endorphin ${ }_{1-31}, \mathrm{~N}$-acetyl- $\beta$-endorphin $_{1-27}$ and $\mathrm{N}$-acetyl- $\beta$-endorphin ${ }_{1-26}$, and has only approximately $12 \%$ molar cross-reactivity with nonacetylated $\beta$-endorphin $n_{1-31}$. The midpoint of the assay averaged $200 \mathrm{fmol} /$ tube.

$A C T H_{1-39}$ RIA. Antiserum no. 21 (final dilution: $1: 80,000)$ is specific for the middle region of $\mathrm{ACTH}_{1-39}$. This antiserum cross-reacts with ACTH biosynthetic intermediate and pro-opiomelanocortin. This antiserum has $10 \%$ molar cross-reactivity with CLIP, but less than $0.1 \%$ molar cross-reactivity with $\alpha$-MSH. The midpoint of this assay averaged 45 fmol/tube.

$\alpha-M S H$ RIA. The $\alpha$-MSH antiserum was a generous gift from Dr. Reiner Martin (Univ. of Ulm, F.R.G.). This antiserum was used at a final concen-

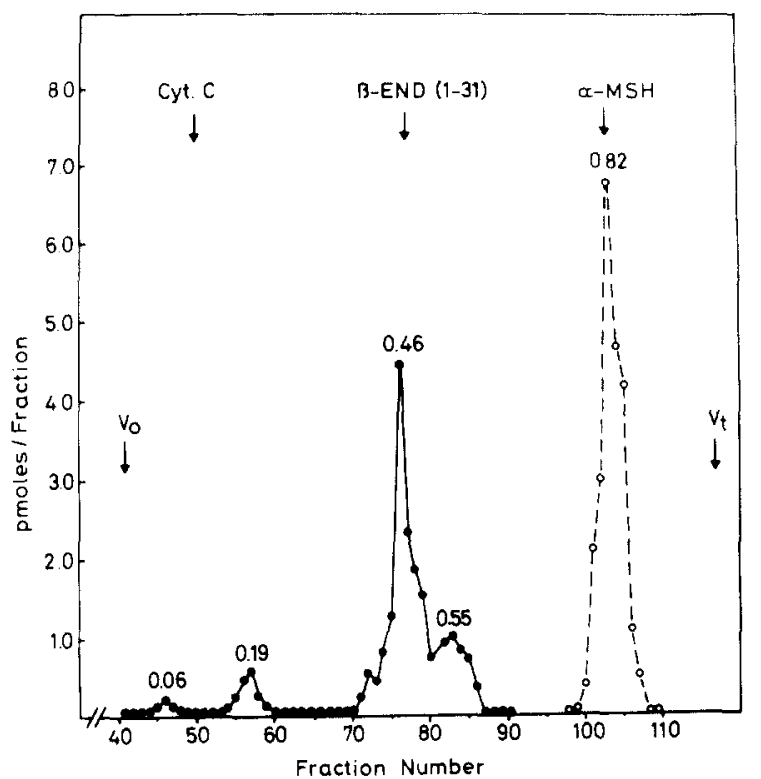

Fig. 2. Gel filtration profile of rat dorsal caudal medulla. An acid extract of 31 rat dorsal caudal medullas $(2.85 \mathrm{~g}$ wet weight) was fractionated by gel filtration on a Sephadex G-50 column ( 1 $\times 100 \mathrm{~cm}$ ) equilibrated in $10 \%$ formic acid $/ 0.01 \%$ bovine serum albumin $/ 0.1 \%$ 2-mercaptoethanol as described in Methods. The solid line (closed circles) represents $\beta$-endorphin-related immunoreactivity detected with antiserum Brenda. The dashed line (open circles) represents $\alpha$-MSH-sized immunoreactivity detected with the Martin antiserum. The total amount of ACTH-sized material detected in fractions 65-75 with antiserum no. 21 appears in Table I. The standards, cytochrome C, synthetic camel $\beta$-endorphin ${ }_{1-31}$ and synthetic $\alpha$-MSH were run separately.

tration of $1: 30,000$ and is specific for the C-terminal of $\alpha$-MSH. The midpoint of this assay averaged 180 fmol/tube.

\section{RESULTS}

Gel filtration analysis of extracts of rat and guinea pig dorsal caudal medulla

Immunohistochemical studies of the rat brain, following pretreatment with colchicine, revealed perikarya in the NTS which contain ACTH-related, $\beta$-LPH-related and $16 \mathrm{kDa}$ fragment-related immunoreactivity ${ }^{19-21,30}$. Preliminary radioimmunoassay analysis of pooled extracts of 5-10 caudal medullas indicated that approximately $750 \pm 175 \mathrm{fmol}$ (mean \pm S.D.; $\mathbf{n}=4$ ) of $\beta$-endorphin-related and $\alpha$-MSHrelated material are present in this region of the rat brain (data not shown). Given these low steady-state levels, a pooled extract of 31 rat caudal medullas and 
20 guinea pig caudal medullas were separately fractionated by gel filtration on a Sephadex G-50 column.

Fractionation of the extracts of the rat caudal medulla revealed several peaks of $\beta$-endorphin-related material (Fig. 2). Two minor peaks of immunoreactivity were detected. These peaks corresponded to precursor-sized material $\left(\mathrm{K}_{\mathrm{av}}=0.06\right)$, and $\beta$-LPHsized material $\left(\mathrm{K}_{\mathrm{av}}=0.19\right)$. These peaks represented, respectively, $3 \%$ and $9 \%$ of the total $\beta$-endorphin-related immunoreactivity. A broad major peak of $\beta$-endorphin-sized immunoreactivity $\left(\mathrm{K}_{\mathrm{av}}=\right.$ 0.46 ) followed by a trailing peak of immunoreactivity $\left(\mathrm{K}_{\mathrm{av}}=0.55\right)$ represented $88 \%$ of the total $\beta$-endorphin-related material. These results are summarized in Table I where the data from Figs. 2 and 3 are expressed as pmol/NTS and pmol/gram NTS. In this extract the molar ratio of $\beta$-LPH-sized material to $\beta$-endorphin-sized material was 1:9.

Aliquots of the fractions depicted in Fig. 2 were also assayed for $\alpha$-MSH immunoreactivity and ACTH immunoreactivity. A major peak of $\alpha$-MSHsized material $\left(\mathrm{K}_{\mathrm{av}}=0.82\right)$ was detected. This peak is roughly equimolar with the peak of $\beta$-endorphinsized material (Table I). Only trace amounts of ACTH-sized material were detected in this extract (Table I). The molar ratio of ACTH-sized material to $\alpha$-MSH-sized material in this extract is approximately $1: 49$. Thus in the rat caudal medulla, $\beta$-endorphinsized material and $\alpha$-MSH-sized material are major end-products, and $\beta$-LPH and ACTH appear to represent biosynthetic intermediates.

Fractionation of an extract of the guinea pig caudal

\section{TABLE I}

Summary of gel filtration analyses

\begin{tabular}{llc}
\hline Peak & pmol/NTS & pmol/g NTS \\
\hline Rat & & \\
Precursor & 0.020 & 0.260 \\
$\beta$-Lipotropin & 0.060 & 0.660 \\
$\beta$-Endorphin & 0.570 & 5.970 \\
ACTH & 0.020 & 0.140 \\
$\alpha$-MSH & 0.660 & 6.880 \\
& & \\
Guinea pig & & \\
Precursor & - & 0.730 \\
$\beta$-Lipotropin & 0.200 & 57.200 \\
$\beta$-Endorphin & 6.010 & 0.430 \\
ACTH & 0.050 & 46.100 \\
$\alpha$-MSH & 4.840 & \\
\hline
\end{tabular}

medulla (Fig. 3) also revealed multiple peaks of $\beta$-endorphin-related material. A minor peak of $\beta$-LPHsized material $\left(\mathrm{K}_{\mathrm{av}}=0.12\right)$ represented $3 \%$ of the total $\beta$-endorphin-related material. A major peak of $\beta$ endorphin-sized material $\left(\mathrm{K}_{\mathrm{av}}=0.47\right)$ with a minor trailing shoulder represented $97 \%$ of the total $\beta$-endorphin-related material. In this extract the molar ratio of $\beta$-LPH-sized material to $\beta$-endorphin-sized material was $1: 30$ (Table I).

Analysis of the column fractions in Fig. 3 with RIAs specific for ACTH and $\alpha$-MSH revealed a major peak of $\alpha$-MSH-sized material $\left(\mathrm{K}_{\mathrm{av}}=0.82\right)$ and only trace amounts of ACTH-sized material (Table I). In the guinea pig caudal medulla extract $\beta$-endorphin-sized material and $\alpha$-MSH-sized material were present in roughly equimolar amounts. Thus at this level of analysis, it appears that proteolytic processing of POMC in the caudal medulla of both species is rather similar. However, a significant difference between the two species is that on a weight basis there is approximately 8-fold more POMC-related material in the guinea pig dorsal caudal medulla as compared to the rat.

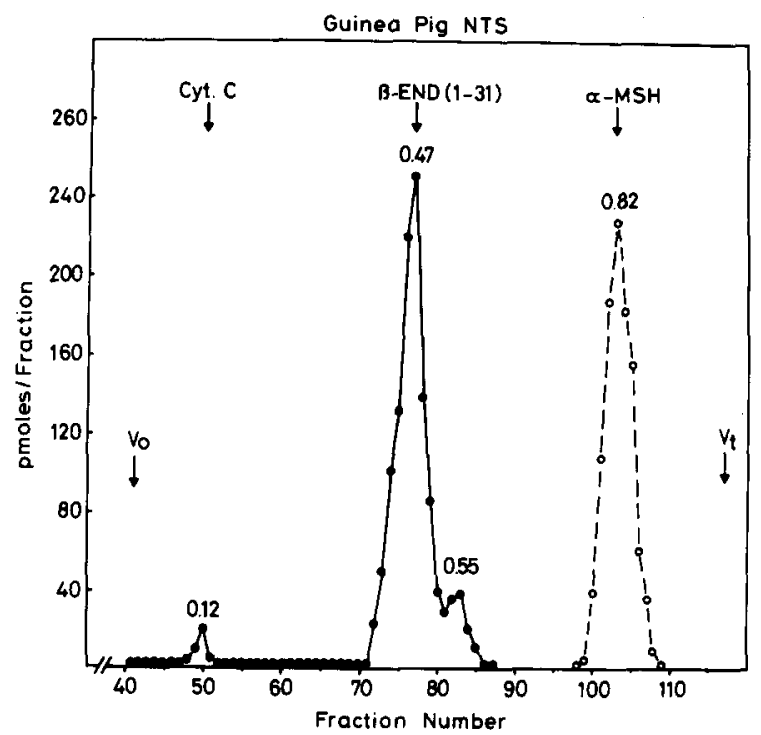

Fig. 3. Gel filtration profile of guinea pig dorsal caudal medulla. An acid extract of 20 guinea pig dorsal caudal medullas were fractionated on a Sephadex G-50 column as described in the legend to Fig. 2 . The solid line (closed circles) represents $\beta$-endorphin-related immunoreactivity detected with antiserum Brenda, and the dashed line (open circles) represents $\alpha$-MSHrelated material detected with the Martin antiserum. The total ACTH-related material detected in fractions 65-75 with antiserum no. 21 appears in Table I. 
Reverse-phase HPLC analysis of $\alpha-M S H$-sized material from extracts of the rat and guinea pig caudal medulla

Based on the gel filtration analyses (Figs. 2 and 3), the forms of $\beta$-endorphin-related material and $\alpha$-MSH-related material appear to be similar to what has been observed in the arcuate nucleus ${ }^{11,14.16 .23 .32}$. In order to determine whether any of the $\alpha$-MSHsized material isolated from the rat and guinea caudal medulla are $\mathrm{N}$-acetylated, aliquots of column fractions corresponding to the peak of $\alpha$-MSH-sized material in Figs. 2 and 3 were separately pooled and analyzed by reverse-phase HPLC.

The rat $\alpha$-MSH-sized material could be fractionated into three minor and two major peaks of immunoreactivity (Fig. 4). The major peaks had the same retention times as synthetic $\mathrm{N}$-acetyl-ACTH $\mathrm{Al}_{1-13} \mathrm{a}$ mide and $\mathrm{N}, \mathrm{O}$-diacetyl-ACTH $\mathrm{H}_{1-13}$ amide, respectively. Collectively, these peaks represented $79 \%$ of the total immunoreactivity recovered by this procedure. A minor peak of immunoreactivity ( $9 \%$ of the total) eluted with the same retention time as synthetic $\mathrm{ACTH}_{1-13}$ amide. Finally, two minor peaks (12\% of

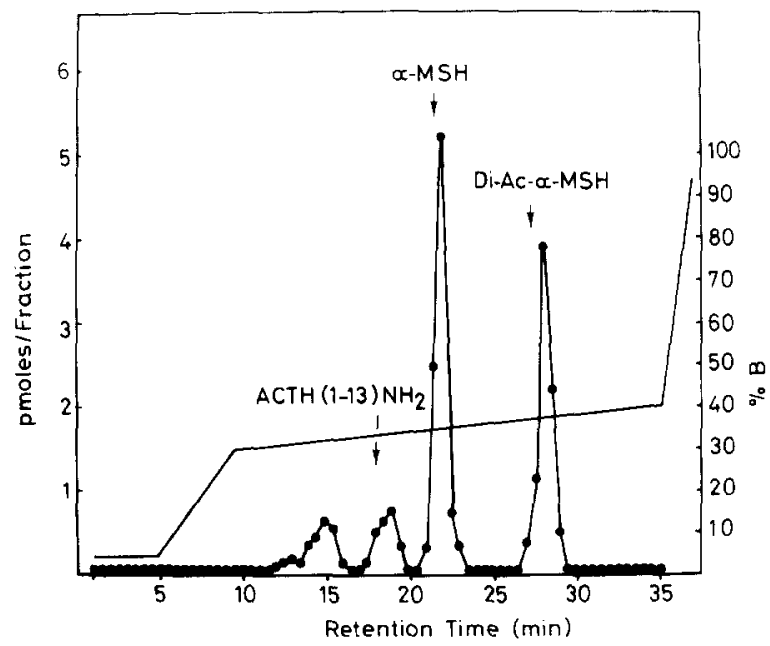

Fig. 4. Reverse-phase HPLC analysis of rat $\alpha$-MSH-sized material. Aliquots $(0.8 \mathrm{ml})$ of fractions $100-110$ from Fig. 2 were pooled and concentrated under vacuum. The dried sample was dissolyed in $0.08 \mathrm{ml}$ of $0.1 \%$ trifluoroacetic acid and chromatographed on a C-18 ODS $5 \mu \mathrm{m}$ column $(4.6 \times 250 \mathrm{~mm})$ equilibrated in $0.1 \%$ trifluoroacetic acid $/ 4 \%$ acetonitrile. The column was eluted with a non-linear acetonitrile gradient at a flow rate of $1 \mathrm{ml} / \mathrm{min}$ and $0.5 \mathrm{ml}$ fractions were collected. Aliquots of column fractions were analyzed with the Martin $\alpha$-MSH RIA (solid line/closed circles). The following synthetic standards were run separately: $\mathrm{ACTH}_{1-13}$ amide, $a$-MSH (mono-acetylated) and di-acetylated- $\alpha$-MSH. the total immunoreactivity) eluted with retention times of oxidized forms of $\alpha$-MSH-related material.

Reverse-phase HPLC analysis of guinea pig $\alpha-\mathrm{MSH}$-sized material also yielded multiple peaks of immunoreactivity (Fig. 5). The major peaks of immunoreactivity have the same retention times as $\mathrm{N}$ acetyl-ACTH ${ }_{1-13}$ amide and N,O-diacetyl-ACTH1-13amide, respectively. Collectively, these peaks represented $85 \%$ of the total immunoreactivity recovered. By contrast, the peak of immunoreactivity with the same retention time as $\mathrm{ACTH}_{1-13}$ amide represented only $4 \%$ of the total immunoreactivity. The remaining $10 \%$ of the recovered immunoreactivity was distributed among minor peaks of apparently oxidized $\alpha$-MSH-related forms which had retention times of $12.5,14.5$ and $25 \mathrm{~min}$.

Ion exchange chromatography of $\beta$-endorphin-sized material from extracts of rat and guinea pig caudal medulla

The detection of acetylated forms of $\alpha-\mathrm{MSH}$ in the extracts of rat and guinea pig NTS raises the issue of whether any of the forms of $\beta$-endorphin are acetylated in this region. The possible linkage between the acetylation of $\alpha-\mathrm{MSH}$ and $\beta$-endorphin in the NTS is based on observations of the acetylation events occurring in the mammalian intermediate pituitary. Several studies suggest that the same or similar ace-

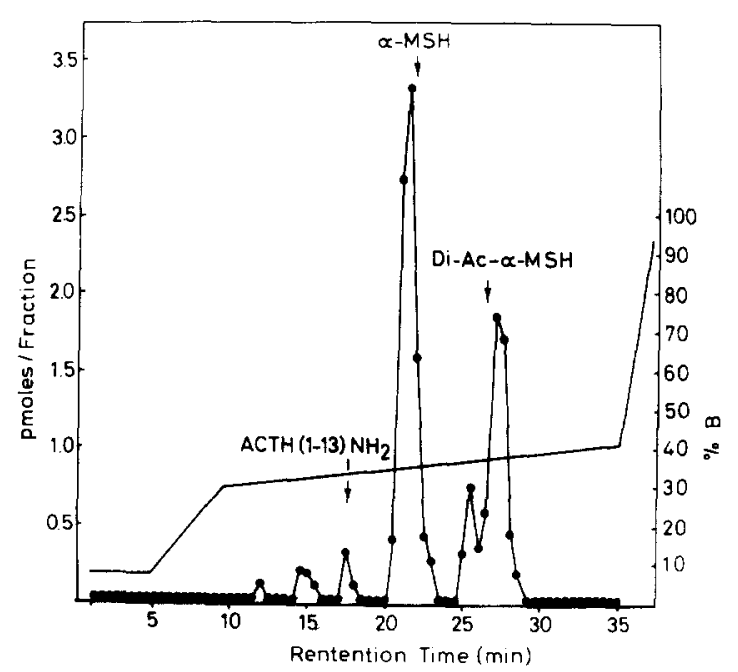

Fig. 5. Reverse-phase HPLC analysis of guinea pig $\alpha$-MSHsized material. Aliquots $(0.1 \mathrm{ml})$ of fractions $100-110$ from Fig. 3 were pooled, concentrated and chromatographed as described in the legend to Fig. 4. 


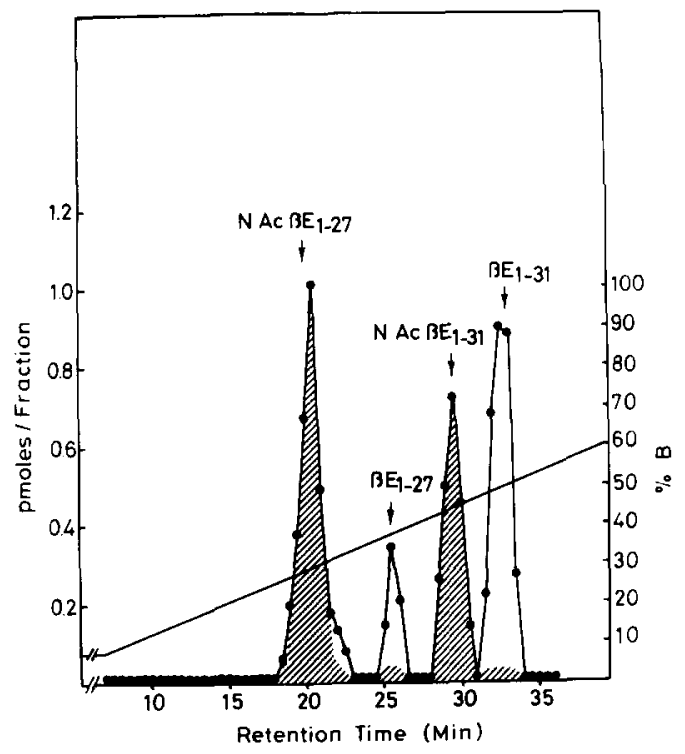

Fig. 6. TSK CM-2SW cation exchange chromatography of rat $\beta$-endorphin-sized material. Aliquots $(0.5 \mathrm{ml})$ of fractions 71-86 from Fig. 2 were pooled and concentrated under vacuum. The dried sample was redissolved in $0.09 \mathrm{ml}$ of $1 \%$ formic acid and chromatographed on a TSK CM-2SW ion exchange column $(4.6 \times 250 \mathrm{~mm})$ as described in Methods. The column was eluted with a linear ammonium formate gradient. The flow rate was $0.6 \mathrm{ml} / \mathrm{min}$ and $0.3 \mathrm{ml}$ fractions were collected. Aliquots of each column fraction were separately assayed with the mid-portion directed $\beta$-endorphin antiserum (Brenda; solid line, closed circles), and the $\mathrm{N}$-acetyl specific $\beta$-endorphin antiserum (Nancy Beth, hatched areas). The following synthetic standards were run separately: $\mathrm{N}-\mathrm{Ac}-\mathrm{BE}_{1-27}-\mathrm{N}$-acetyl- $\beta$-endorphin $_{1-27} ; \mathrm{BE}_{1-27}-\beta$-endorphin ${ }_{1-27} ; \mathrm{N}-\mathrm{Ac}_{-} \mathrm{BE}_{1-31}-\mathrm{N}$ acetyl- $\beta$-endorphin ${ }_{1-31} ; \mathrm{BE}_{1-31}-\beta$-endorphin - $_{1-31}$.

tyltransferase activity may acetylate both $\alpha$-MSH and $\beta$-endorphin ${ }^{6,15}$, in the rat intermediate pituitary.

Analysis of the $\beta$-endorphin-sized material from the rat caudal medulla extract by cation exchange chromatography at $\mathrm{pH} 2.5$ on a TSK CM 2 SW HPLC system (Fig. 6) revealed multiple peaks of immunoreactivity. Using a mid-portion directed $\beta$-endorphin RIA (Brenda), four peaks of immunoreactivity were detected which had the same retention times as synthetic $\mathrm{N}$-acetyl- $\beta$-endorphin ${ }_{1-27}, \beta$-endorphin ${ }_{1-27}, \mathrm{~N}$ acetyl- $\beta$-endorphin ${ }_{1-31}$ and $\beta$-endorphin ${ }_{1-31}$, respectively. Analysis of aliquots of these column fractions with an RIA specific for $\mathrm{N}$-acetylated forms of $\beta$-endorphin (Fig. 6) supported the conclusion that the peaks of immunoreactivity with retention times of 21 min and $29 \mathrm{~min}$ represented acetylated forms of $\beta$-endorphin. The results of this analysis are summarized in Table II. Approximately $65 \%$ of the total $\beta$-endor-
TABLE II

Summary of ion exchange analyses

\begin{tabular}{|c|c|}
\hline Form & $\%$ of total immunoreactivity \\
\hline \multicolumn{2}{|l|}{ Rat } \\
\hline N-Acetyl- $\beta$-endorphin ${ }_{1-27}$ & 39 \\
\hline$\beta$-Endorphin ${ }_{1-27}$ & 9 \\
\hline N-Acetyl- $\beta$-endorphin ${ }_{1-31}$ & 26 \\
\hline$\beta$-Endorphin ${ }_{1-31}$ & 26 \\
\hline \multicolumn{2}{|l|}{ Guinea pig } \\
\hline N-Acetyl- $\beta$-endorphin ${ }_{1-27}$ & 7 \\
\hline$\beta$-Endorphin & 3 \\
\hline N-Acetyl- $\beta$-endorphin ${ }_{1-31}$ & 59 \\
\hline$\beta$-Endorphin ${ }_{1-31}$ & 31 \\
\hline
\end{tabular}

phin in the rat caudal medulla is $\mathrm{N}$-acetylated. In addition, approximately $48 \%$ of the total $\beta$-endorphinsized material is represented by $\beta$-endorphin ${ }_{1-27}$-related forms. Thus both $\mathrm{N}$-acetylation and $\mathrm{C}$-terminal proteolytic modification of $\beta$-endorphin can be demonstrated in the rat caudal medulla.

Analysis of the pool of $\beta$-endorphin-sized material from the guinea pig NTS extract yielded a similar, yet distinct profile (Fig. 7). Peaks of immunoreactivity corresponding to $\mathrm{N}$-acetyl- $\beta$-endorphin ${ }_{1-27}, \beta$-endor-

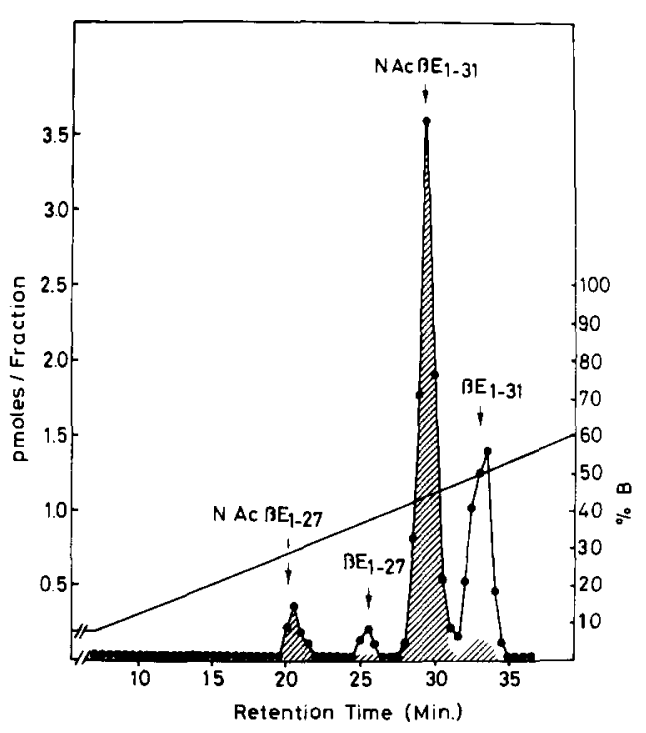

Fig. 7. TSK CM-2SW cation exchange chromatography of guinea pig $\beta$-endorphin-sized material. Aliquots $(0.15 \mathrm{ml})$ of fractions $71-85$ from Fig. 3 were pooled and chromatographed as described in the legend to Fig. 6. Aliquots of each column fraction were separately assayed with the $C$-terminal $\beta$-endorphin antiserum (Brenda; solid line, closed circle), and the Nacetyl-specific $\beta$-endorphin antiserum (Nancy Beth, hatched area). 
$\operatorname{phin}_{1-27} . \quad \mathrm{N}$-acetyl- $\beta$-endorphin ${ }_{1-31}$ and $\beta$-endorphin $_{1-31}$ could be detected. However, the portions of these peaks relative to the rat profile were distinct (Table II). In the guinea pig caudal medulla, approximately $63 \%$ of the $\beta$-endorphin-sized material corresponded to $\mathrm{N}$-acetyl $-\beta$-endorphin ${ }_{1-27}$ and $\mathrm{N}$-acetyl $\beta$ endorphin ${ }_{1-31}$. The identity of these peaks were confirmed with the $\mathrm{N}$-acetyl- $\beta$-endorphin-specific RIA (Fig. 7). However, in the guinea pig extract only $10 \%$ of the total $\beta$-endorphin was $\beta$-endorphin ${ }_{1-27}$-sized. Thus under steady-state conditions the conversion of $\beta$-endorphin ${ }_{1-31}$ to $\beta$-endorphin ${ }_{1-27}$ does not appear to be a significant event in the guinea pig caudal medulla, whereas, the $\mathrm{N}$-acetylation of $\beta$-endorphin in this region does appear to be a major post-translational event.

\section{DISCUSSION}

Anatomical studies have demonstrated that POMC cell bodies are located in the nucleus tractus solitarius $^{19-21.30}$. In this study the steady-state levels of POMC-related products were investigated in the nucleus tractus solitarius and surrounding structures in the dorsal caudal medulla. Gel filtration studies of acid extracts of the dorsal caudal medulla of two species of mammals, the rat and guinea pig, revealed that $\beta$-endorphin-sized material and $\alpha$-MSH-sized material represent the major end products in this region of the brain; $\beta$-LPH and $\mathrm{ACTH}$ represented minor products. At this level of analysis, the proteolytic processing pattern observed in the NTS region is similar to the arcuate POMC system ${ }^{16,23.24}$ and the intermediate pituitary (for reviews see ref. 26). Posttranslational processing of POMC-related products in the dorsal caudal medulla system is distinct from the arcuate system in that mono- and diacetylated forms of $\alpha$-MSH and acetylated forms of $\beta$-endorphin are present in the caudal medulla. This is in contrast to the arcuate system where non-acetylated forms of these POMC end-products predominate ${ }^{11,14,25.32-34}$.

Based on the degree of acetylation of $\alpha-\mathrm{MSH}$, the caudal medulla appears to be very similar to the intermediate pituitary POMC system ${ }^{14.29}$. However, under steady-state conditions, the proportions of $\beta$-endorphin-related material in the caudal medulla as compared to the intermediate pituitary are distinct. In the intermediate pituitary, the major forms of $\beta$-endorphin are $\mathrm{N}$-acetyl- $\beta$-endorphin ${ }_{1-26}, \mathrm{~N}$-acetyl- $\beta$-endorphin ${ }_{1-27}$ and $N$-acetyl- $\beta$-endorphin ${ }_{1-31} ; \beta$ endorphin $_{1-27}$ and $\beta$-endorphin ${ }_{1-31}$ are minor products $1,18,26,32,33$. In the rat caudal medulla $C$-terminal proteolytic cleavage and $\mathrm{N}$-acetylation of $\beta$-endorphin $_{1-31}$ to $\beta$-endorphin ${ }_{1-27}$ occurs, however, under steady-state conditic s, $\mathrm{N}$-acetyl- $\beta$-endorphin ${ }_{1-31}$ and $\beta$-endorphin ${ }_{1-31}$ are major products. In the guinea pig caudal medulla, the $\mathrm{N}$-acetylation of $\beta$-endorphin $_{1-31}$ is a major event; however, under steadystate conditions, the $\mathrm{C}$-terminal proteolytic cleavage of $\beta$-endorphin ${ }_{1-31}$ is a minor event. In both species of rodents, $\mathrm{N}$-acetyl- $\beta$-endorphin ${ }_{1-26}$ does not appear to be a significant product. The mid-portion specific $\beta$-endorphin RIA (Brenda) and the $\mathrm{N}$-acetyl-specific $\beta$-endorphin RIA (Nancy Beth) both recognize $\mathrm{N}$ acetyl- $\beta$-endorphin $_{1-26}$ (ref. 4). Ion exchange chromatography of both the rat and guinea pig caudal medulla revealed only trace levels of $\mathrm{N}$-acetyl- $\beta$-endorphin $_{1-26}$. These levels were very close to the limits of sensitivity of the RIAs employed (data not shown). Given the low levels of POMC-related products in the caudal medulla relative to the pituitary, larger quantities of tissue will be required to convincingly demonstrate the presence of $\mathrm{N}$-acetyl- $\beta$-endorphin $_{1-26}$ in this tissue.

The results of these steady state studies raises the issue of the origin of POMC end products in the caudal medulla. The most parsimonious explanation is that the POMC cell bodies in the NTS are the source of this material. The tissue that was analyzed in this study included the NTS as well as other surrounding processes and cell body regions in the dorsal caudal medulla. In these extracts the molar ratio of $\beta-\mathrm{LPH}$ sized material to $\beta$-endorphin-sized material in the rat caudal medulla was 1:9 (Table I). Analyses of three separate rat caudal medulla extracts gave comparable results (data not shown). The molar ratio of these forms in the arcuate nucleus ${ }^{16}$ and the intermediate pituitary ${ }^{9}$ exceeds 1:50; thus it is unlikely that the arcuate nucleus is the primary source of the POMC products in the caudal medulla. Lesion studies on the arcuate POMC system ${ }^{12,13,45}$ lend support to this conclusion. Recent anatomical studies, however, indicate that although the NTS is probably the major source of POMC material in the dorsal caudal medulla, a small subset of POMC cell bodies in the lateral arcuate region do project to the dorsal vagus 
complex ${ }^{17}$; a region of the dorsal caudal medulla included in these studies. A re-evaluation of the arcuate lesion paradigms should be useful in sorting out the relative contributions of arcuate and NTS POMC perikarya to the total content of POMC-related material in the dorsal caudal medulla.

Another potential source for the POMC products in the dorsal caudal medulla is the pituitary. There is, for example, approximate $300 \mathrm{pmol}$ of $\beta$-endorphin in the rat intermediate pituitary ${ }^{17}$, as compared to only $0.6 \mathrm{pmol}$ in the rat caudal medulla. However, the pituitary as a source of the medulla POMC products seems unlikely for several reasons. The immunohistochemical studies of colchicine-treated animals have revealed a distinct subset of cell bodies in the NTS that reacted positively to antisera directed against various POMC products. If the pituitary was the source of this material, via passage across the blood-brain barrier, one would expect a random distribution of immunoreactivity throughout this region. Furthermore, studies of the uptake, by the CNS, of iodinated $\alpha$-MSH injected systemically, have indicated that only minimal amounts of labelled material were found associated with brain tissue ${ }^{8}$. Finally, it has been observed that hypophysectomy has little effect on the distribution of POMC products in the $\mathrm{CNS}^{31}$. Hypophysectomy is a rather radical procedure that not only deprives an organism of POMC products but all the other pituitary hormones as well.

\section{REFERENCES}

1 Akil, H., Ueda, Y. and Lin, H.L., A sensitive coupled HPLC/RIA technique for the separation of endorphins: multiple forms of beta-endorphin in rat pituitary, Neuropeptides, 1 (1981) 429-446.

2 Akil, H., Young, E., Watson, S.J. and Coy, D.H., Opiate binding properties of naturally occurring $\mathrm{N}$ - and $\mathrm{C}$-terminus modified beta-endorphin, Peptides, 2 (1981) 289-292.

3 Akil, H., Watson, S.J., Young, E., Lewis, M.E., Khachaturian, H. and Walker, J.M., Endogenous opioids: biology and function, Annu. Rev. Neurosci., 7 (1984) 223-255.

4 Akil, H., Shiomi, H. and Matthews, J., Induction of the intermediate pituitary by stress: synthesis and release of a nonopioid form of beta-endorphin, Science, 227 (1984) 424-427.

5 Browne, C.A., Bennett, H.P.J. and Solomon, S., Isolation and characterization of corticotropin- and melanotropin-related peptides from the neurointermediary lobe of the rat pituitary by reverse phase liquid chromatography, Biochemistry, 20 (1981) 4538-4546.

6 Chappell, M.C., Loh, Y.P. and O'Donohue, T.L., Evi-
Thus changes in the levels of peptides in the CNS as a result of this treatment may only indicate that nonspecific effects result following chronic deprivation of all pituitary hormones.

The present study indicates that the dorsal caudal medulla, the site of the NTS POMC perikarya, is a region that contains acetylated forms of $\alpha$-MSH as well as acetylated and non-acetylated forms of $\beta$-endorphin. Since this region of the brain represents an important cardiovascular regulatory center ${ }^{18}$, this information will be useful for designing future studies to determine the role of NTS POMC-related products play in the regulation of cardiovascular functions.

\section{ACKNOWLEDGEMENTS}

We wish to thank Dr. Reiner Martin for providing the $\alpha$-MSH antiserum, Ms. Yasuko Ueda for her work on the HPLC ion exchange procedure, and Ms. Hsia-Lien Lin for her assistance with radioimmunoassays. We are grateful to Mr. Giulio Baldrighi for preparation of the figures, Dr. Henry Khachaturian for his careful reading of this manuscript, and Ms. Adele Henry and Ms. Carrie Sercel for preparation of the manuscript. This research was supported by NIDA Grant DA02265 (H.A.) and Michigan Gastro Intestinal Peptide Center Grant AM34933.

dence for an opiomelanotropin acetyltransferase in the rat pituitary neurointermediate lobe, Peptides, 3 (1982) 405-410.

7 Deakin, J.F., Dostrovsky, J.O. and Smyth, D.G., Influence of $\mathrm{N}$-terminal acetylation and C-terminal proteolysis on the analgesic activity of beta-endorphin, Nature (London), 279 (1980) 74-75.

8 Dupont, A., Kastin, A.J., Labrie, F., Pelletier, G., Puvia$\mathrm{ni}, \mathrm{R}$. and Schally, A.V., Distribution of radioactivity in the organs of the rat and mouse after injection of ${ }^{125}$ I-alpha-melanocyte-stimulating hormone, $J$. Endocrinol., 64 (1978) 237-241.

9 Eipper, B.A. and Mains, R.E., Structure and function of proadrenocorticotropin/endorphin and related peptides, Endocr. Rev., 1 (1980) 247-262.

10 Eipper, B.A. and Mains, R.E., Further analysis of posttranslational processing of beta-endorphin in rat intermediate pituitary, J. Biol. Chem., 256 (1981) 5689-5695.

11 Emeson, R., Post-translational processing of pro-ACTH/ endorphin-derived peptides in rat hypothalamus, Soc. Neurosci. Abstr., 10 (1984) 594.

12 Eskay, R.L., Brownstein, M.J. and Long, R.T., Alpha-me- 
lanocyte-stimulating hormone: reduction in adult rat brain after monosodium glutamate treatment of neonates, $\mathrm{Sci}$ ence, 205 (1979) 827-829.

13 Eskay, R.L., Giraud, P., Oliver, C. and Brownstein, M.J., Distribution of $\alpha$-melanocyte-stimulating hormone in the rat brain: evidence that $\alpha$-MSH-containing cells in the arcuate region send projections to extrahypothalamic areas, Brain Research, 178 (1979) 55-67.

14 Evans, C.J., Lorenz, R., Weber, E. and Barchas, J.D., Variants of alpha-melanocyte stimulating hormone in rat brain and pituitary: evidence that acetylated alpha-MSH exists only in the intermediate lobe of the pituitary, Biochem. Biophys. Res. Commun., 106 (1982) 910-919.

15 Glembotski, C.C., Characterization of the peptide acetyltransferase activity in bovine and rat intermediate pituitaries responsible for the acetylation of beta-endorphin and alpha-MSH, J. Biol. Chem., 257 (1982) 10501-10509.

16 Gramsch, C., Kleber, G., Volker, H., Pasi, A., Mehraein, P. and Herz, A., Pro-opiocortin fragments in human and rat brain: $\beta$-endorphin and $\alpha$-MSH are the predominant peptides, Brain Research, 192 (1980) 109-119.

17 Gray, T.S., O'Donohue, T.L., Watson, S.J. and Magnuson, D.J., Pro-opiomelanocortin and neuropeptide $Y$ projections to arcuate and periarcuate hypothalamic areas to the nucleus tractus solitarius-dorsal vagal complex, Soc. Neurosci. Abstr., 10 (1984) 432.

18 Holaday, J.W., Cardiovascular effects of endogenous opiate systems, Annu. Rev. Pharmacol. Toxicol., 23 (1983) 541-594.

19 Joseph, S.A., Pilcher, W.H. and Bennett-Clarke, C., Immunocytochemical localization of ACTH perikarya in nucleus tractus solitarius: evidence for a second opiocortin neuronal system, Neurosci. Lett., 38 (1983) 221-225.

20 Kawai, Y., Inagaki, S., Shiosaka, S., Shibasaki, T., Ling, N., Tohyama, M. and Shiotani, Y., The distribution and projection of $\gamma$-melanocyte stimulating hormone in the rat brain: an immunohistochemical analysis, Brain Research, 297 (1984) 21-32.

21 Khachaturian, H., Alessi, N.E., Munfakh, N. and Watson, S.J., Ontogeny of opioid and related peptides in the rat CNS and pituitary: an immunocytochemical study, Life Sci., 33 (Supplement 1) (1983) 61-64.

22 Khachaturian, H., Lewis, M.E., Tsou, K. and Watson, S.W., Beta-endorphin, ACTH, alpha-MSH and related peptides. In T. Hokfelt and A. Bjorkland (Eds.), Handbook of Chemical Neuroanatomy, Vol. 3, Elsevier Press, Amsterdam, 1985, in press

23 Liotta, A.S., Loudes, C., McKelvy, J.F. and Krieger,
D.T., Biosynthesis of precursor corticotropin/endorphin-, corticotropin-, alpha-melanotropin, beta-lipotropin, and beta-endorphin-like material by cultured rat hypothalamic neurons, Proc. Natl. Acad. Sci. U.S.A., 77 (1980) $1880-1884$

24 Liotta, A.S., Advis, J.P., Krause, J.E., McKelvy, J.F. and Krieger, D.T., Demonstration of in vivo synthesis of proopiomelanocortin-, beta-endorphin-, and alpha-melanotropin-like species in the adult rat brain, J. Neurosci., 4 (1984) 956-965.

25 Loh, Y.P., Eskay, R.L. and Brownstein, M., Alpha-MSHlike peptides in rat brain: identification and changes in level during development, Biochem. Biophys. Res. Commun., 94 (1980) 916-923.

26 Mains, R.E. and Eipper, B.A., Differences in the processing of beta-endorphin in the rat anterior pituitary and intermediate pituitary, J. Biol. Chem., 256 (1981) 5683-5688.

27 O'Donohue, T.L. and Dorsa, D.M., The opiomelanotropinergic neuronal and endocrine systems, Peptides, 3 (1982) 352-396.

28 O'Donohue, T.L., Miller, R.L. and Jacobowitz, D.M., Identification, characterization and stereotaxic mapping of intraneuronal alpha-melanocyte stimulating hormone-like immunoreactive peptides in discrete regions of the rat brain, Brain Research, 176 (1979) 101-123.

29 Rudman, D., Chawla, R.K. and Hollins, B.M., N,O-Diacetylserine $_{1}$ alpha-melanocyte stimulating hormone, a naturally occurring melanotropic peptide, J. Biol. Chem., 254 (1979) 10102-10108.

30 Schwartzberg, D.S. and Nakane, P.K., ACTH-related peptide containing neurons within the medulla oblongata of the rat, Brain Research, 276 (1983) 351-356.

31 Vaudry, H., Tonon, M.C., Delarue, R., Vailant, R. and Kraicer, J., Biological and radioimmunological evidence for melanocyte stimulating hormone (MSH) of extrapituitary origin in the rat brain, Neuroendocrinology, 27 (1978) $9-24$.

32 Weber, E., Evans, C.J. and Barchas, J.D., Acetylated and nonacetylated forms of beta-endorphin in rat brain and pituitary, Biochem. Biophys. Res. Commun., 103 (1981) 698-705.

33 Zakarian, S. and Smyth, D.G., Distribution of active and inactive forms of beta-endorphin in rat pituitary and brain, Proc. Natl. Acad. Sci. U.S.A., 76 (1979) 5972-5976.

34 Zakarian, S. and Smyth, D.G., Beta-endorphin is processed differently in specific regions of rat pituitary and brain, Nature (London), 296 (1982) 250-252. 